\title{
FAECAL GESTAGEN, SERUM AND MILK PROGESTERONE CONCENTRATIONS IN EWES OF THE JEZERSKO-SOLCHAVA BREED
}

\author{
N. ČEBULJ-KADUNC ${ }^{1}$, T. SNOJ ${ }^{2}$, V. CESTNIK ${ }^{1}$ \\ ${ }^{1}$ Institute of Physiology, Pharmacology and Toxicology, \\ Veterinary Faculty, University of Ljubljana, Slovenia \\ ${ }^{2}$ Center for Artificial Insemination "Preska", Medvode, Slovenia
}

Received September 9, 1999

Accepted February 10, 2000

\begin{abstract}
Čebulj-Kadunc N., T. Snoj, V. Cestnik: Faecal Gestagen, Serum and Milk Progesterone Concentrations in Ewes of the Jezersko-Solchava Breed. Acta Vet. Brno 2000, 69: 33-37.

The aim of the study was to obtain information about the characteristics of the serum progesterone, faecal gestagen and milk progesterone patterns in the ewes during oestrous cycle, pregnancy and postpartum period. The study was performed in seven adult ewes of the JezerskoSolchava breed. The faecal gestagens were extracted by methanol and hormone concentrations determined by EIA. During the oestrous cycle, lasting 16 days in average, low serum progesterone and faecal gestagen values were found in the follicular ( $4.77 \mathrm{nmol} / \mathrm{L}$ and $1.4 \mathrm{nmol} / \mathrm{g}$, respectively) and high values in the luteal phase $(31.34 \mathrm{nmol} / \mathrm{L}$ and $3.26 \mathrm{nmol} / \mathrm{g}$ respectively). They remained high during pregnancy with the mean duration of 145 days, decreased abruptly at parturition and remained low during the early postpartum period. Significant positive correlations were established between the serum progesterone and faecal gestagen concentrations during the oestrous cycle $(r=0.8848, P<0.001)$, pregnancy $(r=0.9129, P<0.001)$ and postpartum period $(r=0.6861$, $\mathrm{P}<0.01$ ). During the postpartum period significant positive correlation existed among the serum and milk progesterone and faecal gestagen concentrations as well. The results of our study show a positive correlation between the serum progesterone and faecal gestagen concentrations in ewes. Therefore we conclude that faecal gestagen determination is a suitable non-invasive method for the estimation of ovarial activity in ewes.

Veterinary medicine, reproduction, progesterone, gestagen, sheep
\end{abstract}

In ewes, low blood progesterone concentrations at ovulation increase markedly during the luteal phase (between days 2 and 10 of oestrous cycle), and during the next follicular phase (between days 16 to18 of oestrous cycle) they decrease again (Gonzales Reyna et al. 1987; Peeters et al. 1989; Rhodes et al. 1990; Gonzales Reyna et al. 1991; Nephew et al. 1991). Differences in serum progesterone levels between the pregnant and cycling ewes appear between days 14 and 18 after oestrus, i.e. in the period of corpus luteum regression in cycling ewes (Rhodes et al. 1990; Döcke 1994). The serum progesterone concentration remains elevated during pregnancy and abruptly decreases at the parturition (Gonzales Reyna et al. 1991; Döcke 1994; Hoffmann 1994). The first silent ovulation occurs between 12 and 25 days post partum but the first behavioural oestrus is possible only after the involution of uterus (Sharpe et al. 1986). The gestagen hormones are mainly inactivated in liver but also in kidneys, lungs, gonads and blood. They are metabolised to water-soluble conjugates and excreted via urine or in bile with faeces, where they can be measured (Döcke 1994; Palme et al. 1996; Schwarzenberger et al. 1996).

The Jezersko-Solchava is a Slovene autochthonous, whole-year polyoestric breed of sheep, mainly used for lamb production. As the endocrinological variables of the breed have not yet been investigated accurately, the aim of the study was to determine the characteristics of the faecal gestagen, serum and milk progesterone pattern during oestrous cycle, pregnancy and early postpartum period.

Address for correspondence:

N. Čebulj-Kadunc, D.V.M., Ph.D.
Institute of Physiology, Pharmacology and Toxicology,

Institute of Physiology

Gerbičeva 60, 1115 Ljubljana, Slovenia
Phone: +386611779100

Fax: +38661332243

E-nail: CebuljN@mail.vf.uni-lj.si 
Animals and sample collection

The investigation was conducted on a group of 7 one-year-old ewes of the Jezersko-Solchava breed (Ovis aries), kept indoors under natural light conditions. The animals were fed hay twice a day and fresh forage in April and May additionally. The commercially prepared forage mixture for pregnant and lactating ewes was added during pregnancy and lactation. Drinking water was provided ad libitum.

The synchronisation of oestrous cycles was performed by vaginal sponges (Chronogest, Intervet Nederlands) and i.m. application of prostaglandin (Dynolitic, Upjohn Nederlands). Oestrus was detected using external oestrus signs and ram behaviour. At the fourth oestrus after synchronisation, the animals were mated. Lambs remained with their dams until the end of the study.

Blood was collected by jugular venipuncture and faeces taken directly from the rectum. After parturition the milk was obtained by milking in glass tubes. All the samples were kept frozen $\left(-20^{\circ} \mathrm{C}\right)$ pending analysis. From the third oestrus after the synchronisation until day 45 after mating and from the fifth pregnancy month until day 10 after parturition the samples were collected every second day and once a week during the pregnancy.

Hormone assays

The serum and milk progesterone as well as faecal gestagen concentrations were determined by commercial EIA kits (Vetoquinol, France). Before assayed the faecal gestagens were extracted by methanol (Schwarzenberger et al. 1996). The absorbencies of the samples were measured by spectrophotometer (MCC340 Labsystem Multiscan) at $405 \mathrm{~nm}$ and the hormone concentrations calculated by computer program Titersoft (The Silicon Lab Version 2.0A). The range of the serum progesterone assay was between 1.59 and 31.80 $\mathrm{nmol} / \mathrm{L}$. Intraassay coefficients of variation $(\mathrm{CV})$ were $8.14 \%$ and $1.33 \%$ at 2.04 and $10.00 \mathrm{nmol} / \mathrm{L}$, respectively. Interassay CV were $9.29 \%$ and $6.37 \%$ at 2.04 and $10.00 \mathrm{nmol} / \mathrm{L}$, respectively. The faecal gestagen assay was in the range between 1.20 and $3.84 \mathrm{nmol} / \mathrm{g}$. Intraassay $\mathrm{CV}$ were $16.90 \%$ and $11.47 \%$ at 1.07 and $3.26 \mathrm{nmol} / \mathrm{g}$, respectively and interassay CV $17.48 \%$ and $13.82 \%$ at 1.07 and $3.26 \mathrm{nmol} / \mathrm{g}$, respectively. The range of the milk progesterone assay was between 3.17 and $95.39 \mathrm{nmol} / \mathrm{L}$ with intraassay $\mathrm{CV} 8.02 \%$ and $2 \%$ at 1.87 and $29.56 \mathrm{nmol} / \mathrm{L}$, respectively.

Statistical evaluation

The statistical calculations were performed by the programme Statistical Package for Social Sciences (SPSS for Windows. Release 8.0.0.) with subprograms One Way and Analysis of Variance. Results were expressed as mean \pm S. E. M. and considered significant at the level $\mathrm{P}<0.05$. Serum progesterone values under 1.59 or over 31.8 $\mathrm{nmol} / \mathrm{L}$ were considered as 1.59 or $31.8 \mathrm{nmol} / \mathrm{L}$ respectively. Faecal gestagen values under 1.2 or over $3.84 \mathrm{nmol} / \mathrm{g}$ were considered as 1.2 or $3.84 \mathrm{nmol} / \mathrm{g}$ respectively.

\section{Results}

The mean daily serum progesterone and faecal gestagen concentrations in the ewes during the oestrous cycle are presented in Fig.1. During the oestrous cycle the serum progesterone as well as the faecal gestagen concentrations were significantly different $(\mathrm{P}<0.01)$. A positive, significant correlation $(\mathrm{r}=0.8848, \mathrm{P}<0.001)$ was detected between the serum progesterone and the faecal gestagen concentrations during the oestrous cycle. Considering visual signs of the oestrus, ram behaviour and progesterone pattern, the duration of oestrous cycle was 14 days in two ewes, 19 days in one ewe and 16 days in the rest of them. Mean oestrous cycle duration was 16 days.

The mean daily serum progesterone and faecal gestagen concentrations in the ewes during the pregnancy and early postpartum period are presented in Fig. 2. Positive significant correlation was found between the serum progesterone and faecal gestagen concentrations $(\mathrm{r}=0.9129 ; \mathrm{P}<0.001)$ during the pregnancy lasting 145 days in average. Comparing pregnant and cycling ewes, significant differences in serum progesterone concentrations were noticed between days 13 to 14 , and days 17 to 18 after oestrus, and in faecal gestagen concentrations between days 7 to 8 , and days 17 to 18 after oestrus (Table 1).

During the postpartum period positive statistically significant correlation was determined among the serum progesterone and the faecal gestagen concentrations $(r=0.6861, P<0.01)$, the serum progesterone and the milk progesterone concentrations $(\mathrm{r}=0.9654, \mathrm{P}<0.001)$ and the milk progesterone and the faecal gestagen concentrations $(\mathrm{r}=0.6896, \mathrm{P}<0.01)$. 


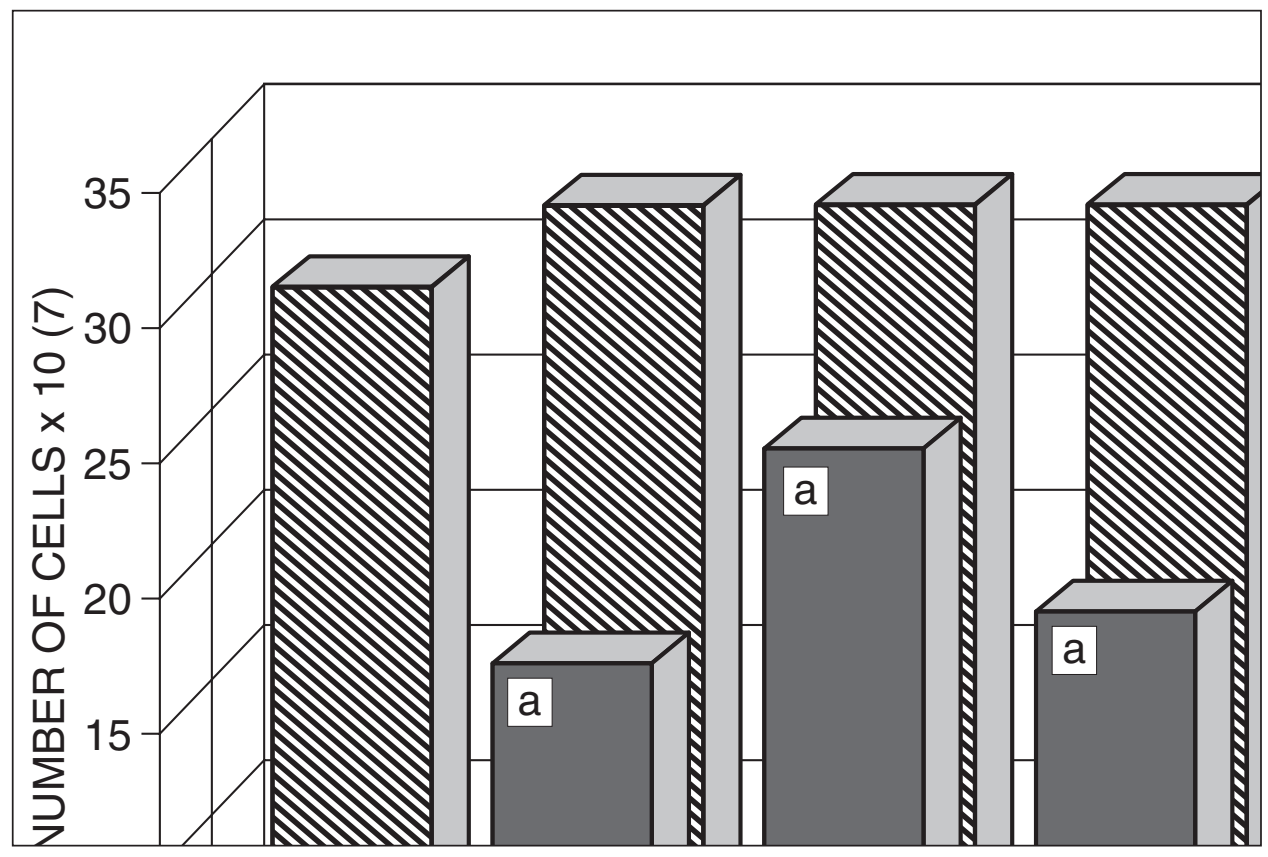

Fig. 1. Mean serum progesterone and faecal gestagen concentrations in the ewes of the Jezersko-Solchava breed $(n=7)$ during the oestrous cycle. Day 0 is the day of oestrus.

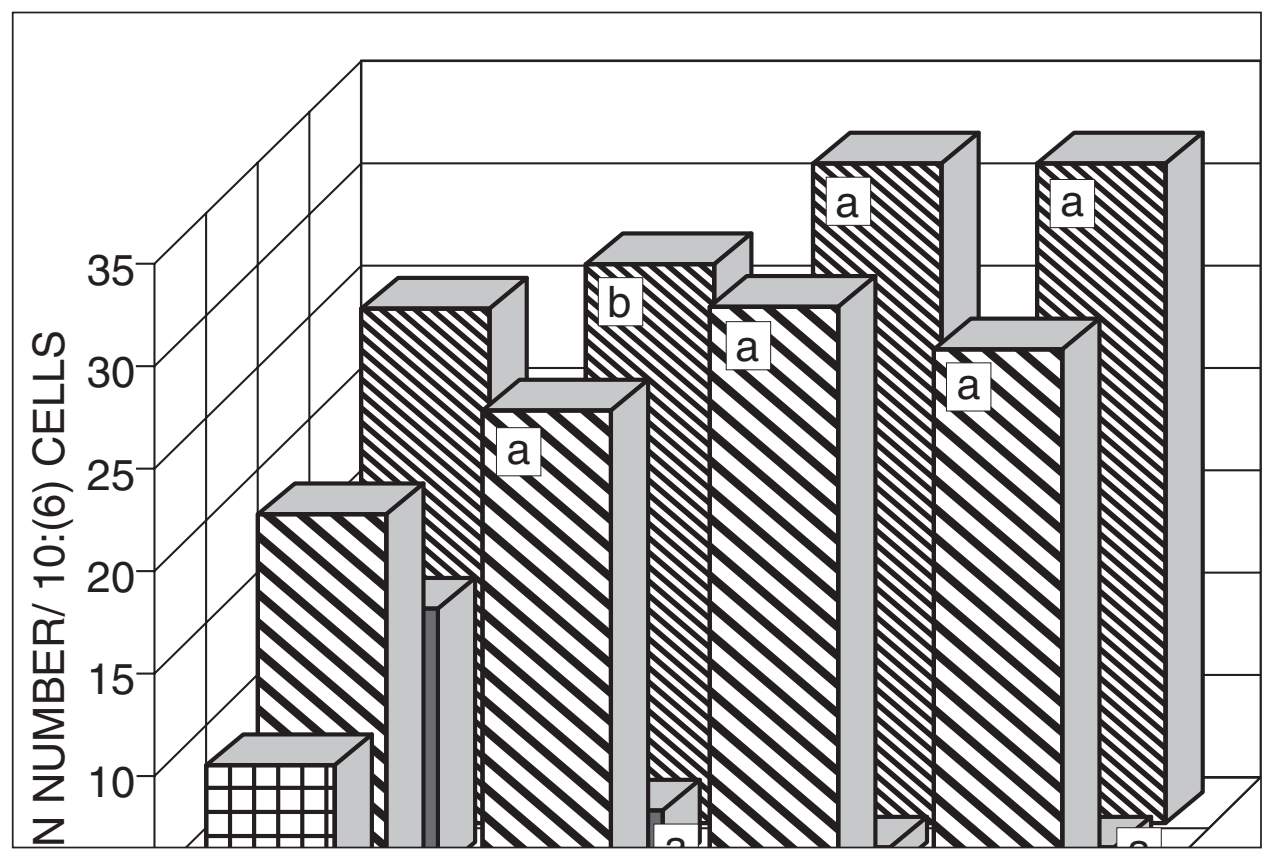

Fig. 2. Mean serum progesterone and faecal gestagen concentrations in the ewes of the Jezersko-Solchava breed $(n=7)$ during the pregnancy and early postpartum period. Day 0 is the day of oestrus. 
Table 1

The serum progesterone and faecal gestagen concentrations (mean \pm S.E.M.) in cycling and early pregnant ewes $(n=7)$.

\begin{tabular}{|c|c|c|c|c|}
\hline & \multicolumn{2}{|c|}{ Serum progesterone (nmol/L) } & \multicolumn{2}{c|}{ Faecal gestagens (nmol/g) } \\
\hline $\begin{array}{c}\text { Days after } \\
\text { oestrus/mating }\end{array}$ & $\begin{array}{c}\text { Oestrous cycle } \\
(\mathrm{n}=7)\end{array}$ & $\begin{array}{c}\text { Pregnancy } \\
(\mathrm{n}=7)\end{array}$ & $\begin{array}{c}\text { Oestrous cycle } \\
(\mathrm{n}=7)\end{array}$ & $\begin{array}{c}\text { Pregnancy } \\
(\mathrm{n}=7)\end{array}$ \\
\hline 0 (oestrus) & $4.77 \pm 0.31$ & $6.44 \pm 0.54$ & $1.40 \pm 0.13$ & $1.5 \pm 0.18$ \\
$1 .-2$. & $6.35 \pm 1.95$ & $7.93 \pm 1.47$ & $1.77 \pm 0.05$ & $1.84 \pm 0.34$ \\
$3 .-4$. & $15.76 \pm 1.79$ & $13.53 \pm 0.23$ & $2.60 \pm 0.19$ & $2.47 \pm 0.39$ \\
$5 .-6$. & $24.01 \pm 1.98$ & $23.28 \pm 3.81$ & $2.72 \pm 0.29$ & $3.11 \pm 0.33$ \\
$7 .-8$. & $26.66 \pm 2.03$ & $22.55 \pm 6.65$ & $2.63 \pm 0.26^{\mathrm{c}}$ & $3.84 \pm 0.00^{\mathrm{d}}$ \\
$9 .-10$. & $28.81 \pm 1.05$ & $26.82 \pm 2.91$ & $2.82 \pm 0.20^{\mathrm{c}}$ & $3.84 \pm 0.00^{\mathrm{d}}$ \\
$11 .-12$. & $31.34 \pm 0.44$ & $29.95 \pm 1.85$ & $3.26 \pm 0.16^{\mathrm{c}}$ & $3.84 \pm 0.00^{\mathrm{d}}$ \\
$13 .-14$. & $24.86 \pm 2.37^{\mathrm{a}}$ & $31.80 \pm 0.00^{\mathrm{b}}$ & $2.96 \pm 0.22^{\mathrm{c}}$ & $3.84 \pm 0.00^{\mathrm{d}}$ \\
$15 .-16$. & $15.15 \pm 2.32^{\mathrm{a}}$ & $29.25 \pm 2.55^{\mathrm{b}}$ & $2.95 \pm 0.30^{\mathrm{c}}$ & $3.73 \pm 0.11^{\mathrm{d}}$ \\
$17 .-18$. & $5.59 \pm 0.39^{\mathrm{e}}$ & $31.22 \pm 0.58^{\mathrm{f}}$ & $1.49 \pm 0.10^{\mathrm{e}}$ & $3.84 \pm 0.00^{\mathrm{f}}$ \\
\hline
\end{tabular}

a,b $\mathrm{P}<0.05 ;{ }^{\mathrm{c}, \mathrm{d}} \mathrm{P}<0.01 ;{ }^{\mathrm{e}, \mathrm{f}} \mathrm{P}<0.001$

\section{Discussion}

The lowest serum progesterone and faecal gestagen values in cycling ewes of the Jezersko-Solchava breed were determined at the day of oestrus and the highest 11 to 12 days later. They were decreasing rapidly during the follicular phase to reach the lowest value 17 to 18 days after the previous oestrus, which indicated that the animals were in heat again (Peeters et al. 1989). The oestrous cycle duration and serum progesterone pattern were the same as reported for seasonal polyoestric breeds (Peeters et al. 1989; R hodes et al. 1990; Nephew et al. 1991; Dickie and Holzmann 1992).

In pregnant ewes serum progesterone concentration was increasing gradually until day 13 to 14 after mating and remained high during the whole pregnancy, as reported in other breeds (Hoffmann 1994). The faecal gestagen concentration was increasing rapidly until day 7 to 8 after mating and remained high until parturition. In most sheep breeds, differences in serum progesterone concentrations between the pregnant and cycling ewes are observed between days 14 and 18 after oestrus (Rhodes et al. 1990; Dickie and Holzmann 1992; Döcke 1994). Possibly due to relatively short oestrous cycles of about 16 days in our group of Jezersko-Solchava ewes, pregnancy detection by serum progesterone determination was possible between days 13 to 14 after mating.

Significant differences in faecal gestagen concentrations between pregnant and cycling ewes were observed from the 7th or 8th day after mating, i.e. 6 days earlier than in serum progesterone concentrations. Some reasons for the somehow paradoxical phenomena could be the extraction procedure and the type of gestagen metabolite which crossreacted with progesterone antibodies. The results of the trial suggest that pregnancy determination in ewes by faecal gestagen measurement might be possible earlier than by other methods (Busch and Bamberg 1990; Dickie and Holzmann 1992; Susmel and Piasentier 1992). Detailed studies should be performed to confirm this presumption.

On the day of parturition, serum progesterone started to decrease, the lowest value was reached 5 to 6 days later and remained low till the end of experiment. The lowest faecal gestagen concentration was determined on the 9 th to 10 th day post partum. The reasons for the delay of four days are probably the process of progesterone metabolism and inactivation as well as the gestagen passage in the gut content (Schwarzenberger et al. 1996).

Positive significant correlation between the serum progesterone and faecal gestagen concentrations was determined during the oestrous cycle, pregnancy and postpartum period. It indicates that the faecal gestagen measurement is a suitable non-invasive method for the detection of reproductive state of ewes, as reported on other animal species ( $\mathrm{B}$ a mberg and Schwarzenberger 1990; Schwarzenberger et al. 1990; Palme et al. 1996). 
The highest milk progesterone concentration was determined on days 1 to 2 after parturition, significantly decreased on days 3 to 4 of lactation and remained low until days 9 to 10 . It was significantly positively correlated to the serum progesterone and faecal gestagen concentrations. This indicates that milk progesterone determination could be also used for the estimation of the ovarial activity of ewes during the postpartum period ( $\mathrm{Busch}$ and Bamberg 1990).

The results of our investigation demonstrate a positive correlation among the serum and milk progesterone and faecal gestagen concentrations in ewes. Therefore we conclude that faecal gestagen determination is a suitable non-invasive method for the estimation of ovarial activity in ewes.

\section{Gestageny ve fécés a koncentrace progesteronu v krevním séru a v mléce bahnic plemene Jezersko-Solchava}

Cílem studie bylo získat údaje o koncentracích progesteronu v krevním séru a v mléce, a gestagenů ve fécés bahnic během estru, gravidity a postpartálního údobí. Bylo použito 7 dospělých bahnic plemene Jezersko-Solchava. Gestageny byly z fécés extrahovány metanolem a koncentrace hormonů stanovena pomocí EIA. V průběhu estru, který trval v průměru 16 dnů, byly zjištěny nízké koncentrace sérového progesteronu. Nízké byly i koncentrace fekálního gestagenu ve folikulární fázi (4.77 nmol/l a 14.nmol/l), zatímco ve fázi luteální byly vysoké (31.34 nmol/l a $3.26 \mathrm{nmol} / \mathrm{l})$; vysoké zůstaly během březosti, která trvala v průměru 145 dní, prudce klesly při porodu a v postpartálním údobí zůstávaly nízké. Signifikantní pozitivní korelace byly zjištěny mezi koncentrací sérového progesteronu a fekálního gestagenu během estru $(\mathrm{r}=0.8848, \mathrm{P}<0.001)$, gravidity $(\mathrm{r}=0.9129, \mathrm{P}<0.001) \mathrm{i}$ post partum $(\mathrm{r}=0.6861 \mathrm{P}<0.01)$. V průběhu postpartálního údobí byla významná pozitivní korelace mezi progesteronem v síru a v mléce a fekálním gestagenem. Výsledky této studie ukazují pozitivní korelace mezi koncentrací sérového progesteronu a fekálního gestagenu u bahnic. Stanovení fekálního gestagenu je vhodnou metodou pro neinvazní měření ovariální aktivity bahnic.

\section{References}

BAMBERG, E., SCHWARZENBERGER, F. 1990: Faecal steroid assay for monitoring of estrus cycle and pregnancy. In: KANEKO, J. J.: Proc. 4 th Cong. Int. Soc. Anim. Clin. Biochem. Davis. Univ. California, pp. 95-99

BUSCH, W., BAMBERG, E. 1990: Trächtigkeitsdiagnose beim Schaff. Tierärztliche Umschau 45: 430-434

DICKIE, M. B., HOLZMANN, A. 1992: Untersuchungen zum Einsatz von Progesteron-schnelltests (Serozyme Progesteron, Ovucheck) zur Graviditäts-diagnose beim österreichischen Bergschaff. J. Vet. Med. Series A 39: 525-530

DÖCKE, F., 1994: Keimdrüsen. In: DÖCKE, F.: Veterinärmedizinische Endokrinologie. Gustav Fischer Verlag, Jena, pp 399-508

GONZALES REYNA, A., MURPHY, B. D., DE ALBA, J., MANNS, J. G. 1987: Endocrinology of the postpartum period in the Pelibuey ewe. J. Anim. Sci. 64: 1717-1723

GONZALES REYNA, A., WALENCIA MENDEZ, J., FOOTE, W. ., MURPHY, B. 1991: Hair sheep in Mexico: reproduction in the Pelibuey sheep. Anim. Breed. Abstr. 59: 509-524

HOFFMANN, B. 1994: Gravidität, Geburt und Puerperium. In: DÖCKE, F: Veterinär-medizinische Endocrinologie. Gustav Fischer Verlag, Jena, pp. 509-546

NEPHEW, K. P., MCCLURE, K. E., OTT, T., DUBOIS, D. H., BAZER, F.W., POPE, W. F. 1991: Relationship between variation in conceptus development and differences in estrus cycle duration in ewes. Biol. Reprod. 44: 536-539

PALME, R., FISCHER, P., SCHILDORFER, H., ISMAIL, M. N., 1996: Excretion of infused ${ }^{14}$ C-steroid hormones via faeces and urine in domestic livestock. Anim. Reprod. Sci. 43: 43-63

PEETERS, R., BUYS, N., PAUWELS, I., KÜHN, E. R., DECUYPERE, E., SIAN, O., VAN ISTERDAEL, J. 1989 : Relationhip between the thyroidal and gonadal axes during the estrus cycle of ewes of different breeds and ages. Reprod. Nutr. Develop. 29: 237-245

RHODES, L., NATHANIELSZ, P. W., 1990: Myometrical activity and plasma progesterone and oxytocin concentrations in cycling and early-pregnant ewes. Biol. Reprod. 41: 834-841 
SCHWARZENBERGER, F., BAMBERG, E., MÖSTL, E. 1990: Monitoring of the oestrus cycle in farm animals by measuring gestagens in faeces. Proceedings of the 8th International Congress on Hormonal Steroids, Hague, pp 1.

SCHWARZENBERGER, F., MÖSTL, E., PALME, R., BAMBERG, E. 1996: Faecal steroid analysis for noninvasive monitoring of reproductive status in farm, wild and zoo animals. Anim. Reprod. Sci. 42: 515-526

SHARPE, P. H., MCKIBBIN, P. E., MURPHY, B. D., MANNS, J.G. 1986: First postpartum ovulations and corpora lutea in ewes which lamb in the breeding season. Anim. Reprod. Sci. 10: 61-74

SPSS for Windows. Releaser 8.0.0. Standard version. Copyright $@$ SPSS., $1989-1997$.

SUSMEL, P., PIASENTIER, E. 1992: Assessment of pregnancy in Bergamasca ewes by analysis of plasma progesterone. Small Ruminant Res. 8: 325 - 332 